\title{
"Homeless" at Home: Linguistic, Cultural, and Identity Hybridity and Third Space Positioning of Kenyan Urban Youth
}

\author{
Lucy Karanja (University of Western Ontario)
}

\begin{abstract}
In Kenyan urban locations where speakers of a myriad of different languages and cultures converge, young people have experienced ambivalence, ambiguity, and contradictions regarding language, culture, and identity that they can ascribe to themselves, both as unifying factors at the national level, as well as marking their identity as urban youth. In an attempt to bridge the ethnic divide, and the divide between what they perceive to be traditional values and the urban, modernized values, Kenyan urban youth have developed a "hybrid" language called "Sheng". This language has opened up avenues for renegotiating their identity and cultures, moving them beyond unitary, fixed identities and binaries of traditional versus urban, and local versus global. Thus, this paper uses the post-colonial notions of hybridity and the third space to interrogate ways in which these youth have challenged the established codes of their identities, and negotiated their ambivalences in a third, hybridized space that is fluid and shifting. Educational opportunities for Kenyan urban youth within the third hybridized space positioning are discussed.

Résumé

$\mathrm{Au}$ Kenya, dans les centres urbains, là où convergent une myriade de langues et de cultures, les jeunes ressentent des contradictions et une certaine ambigüité quant à leur langue, leur culture et leur identité, cette identité qui les caractérise au niveau national comme de jeunes urbains. Ces mêmes jeunes ont développé une langue " hybride " appelée "Sheng" dont le but est clairement de combler la division ethnique, ainsi que la division entre ce qu'ils perçoivent comme étant des valeurs traditionnelles et celles comme étant des valeurs urbaines ou même modernes. Cette langue a ouvert la possibilité de renégocier leurs identités et leurs cultures, et d'aller au-delà même de l'unité, c'est-àdire au-delà des identités fixes et des binaires, tels que traditionnel vs. urbain ou local vs. global. Cet article utilise donc les notions postcoloniales d'hybridité et de troisième espace afin d'analyser la façon dont ces jeunes ont défié les codes établis de leurs identités respectives et comment ils ont négocié leurs ambigüités dans un troisième espace hybride, fluide et variable. Cet article examine également les différentes possibilités éducatives pour les jeunes kenyans urbains dans ce troisième espace hybride.
\end{abstract}

\section{INTRODUCTION}

Multilingual and multicultural contexts are characterized by plurality of cultures and identities, which may require straddling the different cultures and identities. This "neither here nor there" positioning produces ambivalence and contradictions in one's being, compelling one to act towards negotiating the difference. Using the postcolonial notions of hybridity and third space (Bhabha, 1990; 1994), I examine and describe the "in-between" linguistic, cultural, and identity positioning of Kenyan urban youth, which has resulted from the multilingual and multicultural context in which they live. 
Kenya is highly multilingual and multicultural, with over 40 distinct ethnic languages, in addition to Swahili and English. In Kenya, all the languages are socially marked, and these markers function as a loose Kenyan language policy. The tribal languages are associated with ethnic ties but are also socially tied to traditional values and lack of modernization and/or education. Swahili is the national language and a local lingua franca employed mainly for social and commercial communications. It is marked socially as a vehicle for African urbanization, local trade, and blue-collar jobs. On the other hand, English, has been designated as the official language used at all levels of education, for administration purposes, and international trade. At the social level, English is associated with government service, professional, and high profile jobs. It is, therefore, the language of prestige and upward mobility (Kioko \& Muthwii, 2003).

In Kenyan urban locations where speakers of a myriad of different languages and cultures converge, young people have been confronted with choices regarding language, culture, and identity that they can ascribe to themselves both as a unifying factor at the national level, as well as marking their identity as urban youth. Hence, Kenyan urban youth have developed a "hybrid" language called Sheng, which has opened up avenues for them to renegotiate their identity and cultures, thus, moving them beyond unitary, fixed identities and binaries of traditional versus urban, and local versus global, to a third hybridized space that is fluid and shifting. The 'hybrid' identities that Sheng has enabled have presented these youth with the opportunity to view themselves as urbanized by internalizing the popular cultural artifacts and behavior while at the same time keeping in touch with their ethnicity, since Sheng allows them to add words from their tribal languages as it evolves and develops (Abdulaziz \& Osinde, 1997). Therefore, the development of Sheng can be viewed as an effort at establishing a language that is socially neutral, capable of expressing their mixed identities (Samper, 2002).

Sheng, is not a new phenomenon in Kenyan urban spaces, as Mazrui (1995) speculates that it existed in the colonial times in the 1930s among the underworld "professionals" in Nairobi. Additionally, other urban youth languages have emerged in other African countries such as Ivory Coast, Cameroon, and South Africa, among others (Kiessling \& Mous, 2004). However, Sheng's uniqueness lies mainly in its functions among its speakers, and its extensive use among urban high school youth. Furthermore, factors behind Sheng's formation are extra-linguistic, as Swahili exists as a lingua franca that these youth could use for communication. Hence, these factors distinguish Sheng from other language varieties such as creoles and pidgins, which are formulated in the absence of a common medium of communication (Mazrui, 1995). Thus, there is a need to understand the roles that this language plays in the lives of Kenyan urban youth and interrogate educational possibilities that exist for this group. This is particularly urgent at this era when 
the use of Sheng and foreign languages such as English has been blamed for the declining quality of education in Kenya (Momanyi, 2009; Githiora, 2002; Mule, 1999).

The organization of the rest of the paper is as follows: First, I locate myself in the broader discourse of postcoloniality, "hybridity" and the "third space", and elucidate my interest and commitment in examining the issues facing urban youth in Kenya. Second, I draw from and discuss Homi Bhabha's (Bhabha, 1990; 1994) notions of hybridity and the third space, in order to show their utility and relevance in the analysis of the situation of Kenyan urban youth. Third, I provide an overview of Sheng including its formation, functions, and examples of words in this language. Fourth, I will embark on a close examination of the different opposing perspectives, namely: tradition and urbanization, local and foreign/international languages, and localization and globalization that these youth are negotiating in the third space. Finally, I examine pedagogical possibilities that reflect an understanding and accommodation of the new positioning of Kenyan urban youth.

\section{METHODOLOGY AND "IN-BETWEEN" SELF}

Despite Sheng being used by urban youth in Kenya for some years, it was not until in the 1990s in my tenure as a high school teacher in an urban setting, that I experienced its prevalence among the students. At the time, the business of everyday teaching duties and responsibilities took my attention away from thinking critically about the effects of Sheng on these youth's education beyond the casual lament that it prevented proper learning of English and Swahili languages. However, as a young Kenyan scholar who has crossed both imaginary and physical boundaries, I have broadened my experiences with different locations, cultures, and histories. Here, issues of language, culture, identity, and even race have been fore-grounded, necessitating that I negotiate these differences in a third space.

Thus, this third space positioning has provided me with the opportunity to reflect on, and understand (post)-colonial effects on my past and present. It has also prompted me to reflect on the use of Sheng by Kenyan urban youth, and especially on its effects on their interactions and education. Asher (2005) argues that the processes of decolonization and social transformation are self-reflexive, which require the deconstruction of the colonizer and the external oppressive practices as well as examining one's internalization and participation in the same practices. This means understanding the "other" in relation to, rather than apart from, oneself, and vice versa.

Consequently, the investigational methodology utilized in this theoretical paper is observation and experience-based. On the one hand, the appeal for post-colonial theory that provides the framework for this paper emanates from my own understanding of and experiences in post-colonial Kenya. This theory has provided me the structure to re-construct my experiences 
outside the Kenyan context. On the other hand, the information and examples of Sheng words that I provide in this paper result from my own knowledge and experiences with the language, informal observations and consultations with urban youth, and from Sheng-related literature.

\section{HYBRIDITY AND THE THIRD SPACE}

Postcolonial writers (e.g., Ashcroft, Griffiths, \& Tiffins, 1995; Spivak, 1999) have challenged the dominant views by resisting coding, rigidity, and colonialism. They have attended to issues of power, essentialism, and inequality, and probed questions of third space, hybridity, and interstices (English, 2005). Postcolonial writing has engaged the kind of thinking that deconstructs the operations of Eurocentricism as manifested in colonialism and neocolonialism, and the diverse material effects which have resulted from these enterprises. The goal of this deconstruction is to develop alternative interpretations and ideas based on different and diverse ways of knowing (Hickling-Hudson, 2006).

Grounded in postcolonial discourse, and drawing from Bhabha's (Bhabha, 1990; 1994) cultural theory, the concepts of hybridity and third space have become useful, especially in the deconstruction of the paradoxical and contradictory ways in which identity has been conceived. They have, for example, played an important role in problematizing identity in the postcolonial work on borderlands (for example, see Anzaldua, 1987). According to Hoogvelt (1997), the concept of hybridity occupies a central place in postcolonial discourse as one of the "reverse value-coding" strategies that are central to postcolonialism.

Historically, "hybridity" was viewed as a problematic, and even an offensive term. In the colonial era, hybridity was an abusive term, representing the lowest possible form of human life-mixed-breeds of white and other races (Young, 1995). In postcolonial discourse, however, "hybridity is celebrated and privileged as a kind of superior cultural intelligence owing to the advantage of 'in-betweenness', the straddling of two cultures and the subsequent ability to 'negotiate the difference' (Hoogvelt, 1997, p.158). In this sense, hybridity can be viewed as a theoretical lens for understanding diversity, multiplicity, and conflicting perspectives (Gutiérrez, Baquedano-López, \& Tejeda, 1999). This multiplicity produces ambivalence and contradictions in one's existence and in order to resolve these conflicts, one needs to act rather than react. One has to engage that which is antagonistic differently, and move beyond the binaries of the self and the other, the oppressor and oppressed, in order to arrive at a consciousness of one's borderlands, a mestiza consciousness, which is itself a "hybrid consciousness" (Anzaldúa 1987).

According to Bhabha (1994), hybridity involves the struggle of the dominant groups undertaking to define the identity of the other within a unitary, essentializing framework, in contexts where cultural and linguistic practices, as well as histories and epistemologies clash. Hybridity, therefore, counteracts 
essentialism that defines culture and identity as fixed. Challenging and counteracting essentialist views of identity are crucial in the formation of a new hybrid identity or subject position that emerges from the entwining of aspects of the dominant beliefs and practices with those of the other. For Bhabha (1990), hybridity is about the fact that "when a new situation, a new alliance formulates itself, it may demand that you should translate your principles, rethink them, extend them" (p.216). In addition, hybridity provides for a [third] space of resistance, negotiation, and articulation of new meanings in the face of ambivalences, normalization, and hegemony. Thus, Sheng represents attempts by the Kenyan urban youth at extending their definition beyond the normalized ethnic and localized identities.

Bhabha (1990) has conceived the third space as a liminal, in-between space where the established hegemonic and normalizing practices are challenged, re-articulated, and negotiated. This space signifies a resistance to polarization, binaries, labels, and unitary identities. It is a space that is fluid, shifting, and political. In Bhabha's cultural studies theorizing where the use of the concept "third space" has proliferated, it has been understood to indicate the place where life in all its ambiguities is exposed, the ambiguities negotiated, and where identity is constructed and re-constructed, resulting in new identities and possibilities. According to Bhabha:

The importance of hybridity is not to be able to trace two original moments from which the third emerges, rather, hybridity... is the 'Third Space', which enables other positions to emerge. This third space displaces the histories that constitute it, and sets up new structures of authority. (p. 211)

In order to transverse differences and enable the emergence of new cultural and identity definitions and meanings, there is need to question and resist the established and rigid norms that provide limiting views of the other. The third space allows for the interruption and interrogation of restrictive forms of [cultural] meaning, resulting in the enunciation of new forms of meanings and production. The third space, therefore, serves as a corrective to regulative, hegemonic views, and suggests that identity and culture are complex, ambivalent, and negotiable entities, which reject fixity and polarization (Bhabha, 1994). Bhabha points out that although the third space is one of contradictions, ambiguities, and ambivalences, it enables negotiation of inclusion rather than exclusion and becomes a site for innovation, collaboration, and contestation of meanings.

\section{SHENG}

Different studies cite different times of Sheng's conception (Mazrui, 1995; Spyropoulos, 1987). Despite a lack of consensus on Sheng's formation, it is accepted that it originated in the less-affluent and slum areas of Eastlands of 
Nairobi. However, Sheng usage has expanded to middle class youth in other parts of Nairobi and other urban centers in Kenya (Abdulaziz \& Osinde, 1997; Samper, 2002). Additionally, youth in rural areas and even adults familiar with the older version of Sheng are also starting to identity with its usage (Bosire, 2008). Mazrui (1995) attributes the spread of Sheng to middle class youth to the fact that class formation in Kenya is a relatively fluid phenomenon, with social class boundaries yet to be fully solidified.

Kiessling and Mous (2004) identify three key functions of Sheng for the Kenyan urban youth. First, Sheng marks group identity as it operates within a closed in-group. This identity is achieved through the youth distancing themselves from the older generations, the rural, traditional population and lifestyle, and from the upper social classes; indeed, from the rest of society. Second, it functions to bridge ethnic differences in the city and other urban spaces. These youth have made conscious attempts at abandoning ethnicity as an identifying category. Third, Sheng is an icon of urban youth culture. Apart from marking difference and urban youth identity, this language marks these youth's subculture as signified by music, dance, clothing, hair style, comic books, walking styles, and a distinct lifestyle.

Sheng's base languages are English, Swahili, and Kenya's ethnic languages such as Kikuyu, Luo, and Luyha. However, it borrows and includes words from Hindi and Gujarati, western tourists, foreign films and news (Samper, 2002; Spyropoulos, 1987). Despite these sources of Sheng's lexicon, it is Swahili that provides its grammatical framework (Abdulaziz \& Osinde, 1997; Momanyi, 2009). Sheng lexicalization follows an array of linguistic manipulations and innovations, which are, in my view, hybridized. The various linguistic manipulations and innovations are beyond the scope of this paper (see Ogechi, 2005; Kiessling \& Mous, 2004 for detailed information). However, three of these strategies are mentioned in examples of Sheng words below.

1. Word borrowing: This involves borrowing words from any of Sheng's base languages. However, once borrowed, words retain their meanings in the original language or may acquire expanded meanings.

$\begin{array}{cll}\text { Examples: } \frac{\text { Word }}{\text { Ngiri }} & \text { Meaning(s) } & \text { Origin language } \\ \text { Stoori } & \text { story /new information/greetings } & \text { English } \\ \text { Chora } & \text { employ/draw } & \text { Swahili } \\ \text { Buda } & \text { old man/father } & \text { Hindi/Gujarati }\end{array}$

2. Truncation. This entails dropping either the initial or final syllable of a word and then suffixing either a coined syllable or sound to complete its marking for Sheng (Ogechi, 2005). The most common sounds are /sh/, /e/, /i/, and /o/ (Momanyi, 2009). Here are some examples:

$$
\text { Jacket - Jakoo }
$$


Fifty - finje

Dereva (Swahili for 'driver') — deree

Mtoto (Swahili for 'child') — mtoi

Mtumba (second hand clothing) — Mtush

Words' initial syllables can also be truncated as in the example below: Practice Practizi prac- tizi

3. Coining: A Sheng word is considered coined when it does not seem to derive from any of Sheng's base languages. Bosire (2009) outlines various word-coining processes and examples in Sheng. Below are two examples:

a. Coined words not sourced from or based on any of the existing contact languages:

Chappa/niadu/much

Sanya/gondi/hamo

Kemfa/korona/poko money

steal

prostitute

b. Meaning extensions/associations where words derive from topical or current news items with names or incidences in the news become associated with local event, issues, or objects
Kosovo
dangerous place (from the war in Bosnia/Serbia)
Jurassic whore (from the movie Jurassic park)
Rwanda beat up/kill (from Rwanda genocide)
Obama popular beer brand (from rising fame of Barack Obama).

\section{ENGAGING THE THIRD SPACE}

Negotiating between local and foreign/international languages

The language of the conqueror in the mouth of the conquered is the language of slave. (Steyn, Boer leader, 1913, cited in Prah, 1998)

Before examining ways in which Kenyan urban youth have negotiated between local languages and English, and ways in which they may have benefited from this negotiation, it is important to explore ways in which a foreign language such as English may be viewed by these youth, and how it may have influenced their choice of a different language for their day-to-day communication. Ashcroft et al. (1995) have pointed out that, among other things, postcolonial theory investigates conceptions and actions that are, or appear to be, complicit with the imperial enterprise. In addition, the third space is concerned with ambiguities, ambivalences, and contradictions that may arise 
from engaging in an act that is viewed to be complicit. The use of English in postcolonial countries has been viewed as a complicit act with colonialism, owing to the fact that it was the language of the colonizers. This perception was a topic of debate among postcolonial literary writers such as Aschcroft et al. (1989) and Ngugi wa Thiongo, (1986), among others, who first found a voice through literary writing. While mixed feelings abounded regarding this matter among these literary writers, many concluded that the use of foreign languages was indispensable as a means of communicating with the outside world (Egejuru, 1980).

The importance of European languages as indicated by some postcolonial literary writers has been endorsed in many postcolonial countries. Sonaiya (2003) observes that the world has entered an era of globalization of communication in which a few foreign/international languages have been promoted, and are being learned in many parts of the world. She points out that although the use of foreign languages in postcolonial countries is not neutral, the "time is ripe for stripping the continued use of European languages in [postcolonial countries] of its historical burden of colonialism and adopting a functional approach whereby the languages are seen as performing specific functions related to modern living" (p.146). In Kenya, English has increasingly gained prominence not only as the official language but also as the language of instruction at all levels of schooling, for administrative purposes, and international trade.

Questions worth posing at this point are: why have Kenyan urban youth experienced contradictions and ambivalence regarding what language(s) to use, despite the many local languages available to them, and despite the prominence that English has enjoyed in the country? What has pushed them to negotiate, in a third space, a new "hybrid" language of day-to-day communication in a third space?

In the Kenyan urban areas where speakers of different languages coexist, people lack the opportunity to use their ethnic languages, resulting in code-switching mainly between ethnic languages and Swahili, and, to some extent, English. This trend has resulted in lack of proper mastery of any of the languages by the urban youth, including the English language, despite its official status and its use as a medium of instruction in schools (Samper, 2002). As a result, these youth have been left without a local language that they can identify with, and the use of English, which they have also not mastered well, may seem contradictory for two reasons. First, English does not represent their identity and culture, and, second, the official status that has been ascribed to it may make it unsuitable for the social function of day-to-day communication. Prah (1998) observes that languages enable people to express their culture and are the window through which they understand the world and are themselves understood. Prah underscores the importance of a language that one has mastered well in expressing him/herself in relation to the world: 
It is in language that people find their mental home, their definitional relationship to the external world. What this also means is that people can hardly be themselves in an idiom in which they have difficulty understanding or expressing themselves. They can barely be creative and innovative in a language they have to struggle with in order to command expression. (p.2)

Sonaiya (2003) argues that the basic function that needs to be performed by language is that of identity. Drawing from the above analysis of the language situation in Kenyan urban contexts, it is clear that Kenyan urban youth lack an identity language. These youth are engaged in negotiating multiple and shifting identities in their own communities, as young urban people, as members of a nation, and as youth in the global world drawn to the consumption of the global and economic capital. Without a language that will enable them to define themselves and transcend the various identity boundaries, these youth will remain in the borderlands of their identity, causing them to view themselves in terms of self and the other binaries, and forcing them to stay within the established essentializing and normalizing definitions of who they are. They become people in the borderlands who have been described by Asher (2005) as experiencing multiple, opposing identifications, and who struggle to arrive at meaningful synthesis across differences.

In this regard, I argue that the formulation of Sheng by Kenyan urban youth is a result of negotiation in the third space, of the kind of language that they perceive to be representative of their identity and culture. Sheng brings together and accommodates youth from different ethnic backgrounds, forming a new unified identity of urban youth (Kiessling \& Mous, 2004). Thus, it has provided for them a space where their different languages and identities are accommodated, and in which they "can live fearlessly in and within difference (s)" (Trinh, 1989, p.84). By formulating a "hybrid" language that uses words from ethnic languages and English, I argue that these youth have negotiated, even subverted the languages and produced a new language. According to Bhabha (1990), "we are always negotiating in any situation of ...oppression or antagonism. Subversion is negotiation; transgression is negotiation" (p. 216). Ashcroft (2001) has described this kind of negotiation as an engagement of that which is antagonistic in a different way, altering it into tools that express a deeply felt sense of identity and culture.

The fact that Sheng borrows words and grammar from English suggests that Kenyan urban youth have not rejected English and are cognizant of the educational role it plays in their lives. In addition, Sonaiya (2003) points out the important role of English and other few foreign languages in international communication. However, Sonaiya notes that other languages may be chosen in order to allow for the development of personal interests in the current world "without borders". She suggests that in a multilingual setting, such a language 
would be one that is freely chosen, not imposed. In postcolonial countries, she acknowledges that English may have a low chance of being chosen for this purpose because it is prone to accusations of imperialism. While Kenyan youth may continue to learn English for educational and global communication purposes, it is worth considering ways in which Sheng has served other important purposes in their lives, including opening the world to them in ways that English alone may not do. This role of Sheng in the lives of Kenya urban youth will be discussed in a later section in this paper.

\section{Connecting the traditional and the urban}

So...no culture is full unto itself, no culture is plainly plenitudinous, not only because there are other cultures which contradict its authority, but also because its own symbol-forming activity, its own interpellation in the process of representation, language, signification and meaningmaking always underscores the claim to an originality, holistic, organic identity. (Bhabha, 1990, p.210)

Kenyan urban youth articulate their cultural identities in terms of two main competing discourses namely; tradition and urbanization. They view their parents as representative of tradition as signified by ethnic languages, and they as representative of urbanization as marked by urban and youth culture (Samper, 2002). A search for an ethnic cultural identity by Kenyan urban youth would be thwarted by the earlier observation in this paper that their parents, who are residents of urban areas, engage in code-switching and code-mixing of the available languages, resulting in a lack of clearly-demarcated ethnic cultural identities. This cultural situation underscores Bhabha's (1994) assertion that pure cultures do not exist but rather that they are always in the process of redefinition and always in the process of hybridity. Kenyan youth can, therefore, be described as straddling already hybridized ethnic cultural identities as well as youth and urban cultures promoted by popular media.

The hybridized cultural identity of Kenyan urban youth has resulted in a dilemma, ambivalence, and contradiction as they attempt to identify with the traditional cultures and the culture representing urbanization. Prazak (1999), for example, found that although Kenyan urban youth did not want to follow their parents' traditional culture because they found it to be "inferior, outmoded, and insufficient for success in today's world" (p. 93), they demonstrated a reluctance to completely abandon those values. Their simultaneous attempt to identify with both cultures while at the same time rejecting both of them moves them to a third space of negotiation and articulation of difference, resulting in the production of a new understanding of their cultural identity. According to Bhabha (1994), the third space is an ambivalent site where cultural meaning and representation "have no primordial unity or fixity; [and] that even the signs can 
be appropriated, translated...and read a new" (p. 37). This has led Kenyan urban youth to rethink and extend cultural meanings through the formulation and usage of Sheng, a hybrid language which "cuts across obsolete boundaries of ethnic languages and contradicts the purism of colonial language regimes" (Keissling \& Mous, 2004, p. 332).

The formulation of Sheng signals tensions and struggles between the traditional and urban values, and provides a way of accommodating the youth's different cultural identities. As illustrated above, Sheng depends on words and grammar from the various ethnic languages as well as English and Swahili. As it evolves and develops, more words are added from these languages, hence, presenting these youth with an opportunity to keep in touch with their ethnic cultures while at the same time engaging in youth and urban culture through the internalization of popular cultural artifacts such as music, clothing, and behavior (Samper, 2002). The third space has, therefore, allowed Kenyan urban youth to challenge established limiting categorization of culture and identity and enabled them to go beyond the binaries of the traditional and the urbanized. Furthermore, it has provided them with grounds for including, rather than excluding, the different linguistic and cultural identities to which they subscribe (Bhabha, 1994).

\section{UNMAPPING LOCAL AND GLOBAL BOUNDARIES}

It is hybridity all the way down. (Rosaldo, 1995, p. xv)

Understanding ways and conditions under which Kenyan urban youth have negotiated new positions and identities across the local and the global requires an understanding of the conceptualization of globalization, and its relation with localization. Although the conceptualizations of globalization are as varied as the disciplines that define it, two most common interpretations of globalization are considered here. First, globalization is conceived as a process of homogenization in which the world is becoming more uniform and standardized through technological, commercial, and cultural amalgamation. Second, globalization is closely associated with modernity, which, in effect, conceives globalization as Westernization (Pieterse, 1994). According to Pieterse (1994), these understandings of globalization are limiting, with the second conceptualization being geographically narrow (that globalization begins in the West) and historically shallow (that globalization began at a particular time in the West). He asserts that all societies have created their own modernity, which has followed different paths from that of the West.

Pieterse (1994) advocates for viewing globalization as hybridization; the emergence of new, mixed forms of cooperation, and cultural hybridization, or the development of translocal (more open) mélange cultures (p. 161). Giddens (1990) advocates for a similar, and more general view of globalization 
as the intensification of worldwide social relations which connect far localities in such a way that local undertakings are shaped by events happening in distant places and vice versa. According to Pieterse, the conceptualization of globalization as the intensification of word-wide social relations assumes a preexistence of such relations in processes such as immigration, trade connections, and political alliances, among other forms of interactions, between the local and the global. In addition, this conceptualization denotes a continued process of the formation of world wide social relations. This takes the understanding of globalization beyond the history of the West to the history of the world.

The above views of globalization suggest that the polarization between the local and the global, which attributes their separateness to westernization and homogenization, is not tenable. The considerable interaction between the local and the global undermines any approach to consider them as distinct categories (Kraidy, 1999). Kwame (1992, cited in Pieterse, 1994, p. 178), points out that, "if there is a lesson in the broad shape of this circulation of cultures, it is surely that we are all already contaminated by each other, that there is no longer a fully autochthonous...culture awaiting salvage by our artists" (p. 155). Perspectives focused on [cultural] hybridity and not fraught with assumptions of distinct divisions between the local and the global become important starting points for understanding the complex interactions between the local and the global (Kraidy, 1999).

Kenyan urban youth have negotiated a third space position between the local and the global in a complex way, which illustrates the blurring of the boundaries between these two spaces. Sheng is used by these youth to internalize and express a culture that has defined them as Kenyan urban youth and also as youth in relation to the rest of the world. Sheng is a vehicle for popular culture that these youth have taken on, as exposed and promoted to them through the mass media, the internet, and cellular phones. In addition, these youth have taken on hip-hop and rap music and culture as part of the larger popular culture, which brings with it types of clothing and behavior. By taking on popular culture of the world, Kenyan urban youth have moved beyond the essentialized racial, spatial and temporal definitions of themselves as young people in a particular place and time, hence blurring the binaries of the local as represented by themselves and the global as represented by other young people in other parts of the world.

By adopting hip-hop and rap music and culture, I argue that Kenyan urban youth have subverted the West as the source of modernity. The origin of hip-hop and rap music and culture is traced to the West, among the African American people. What is worth noting is that these people belong to the African diaspora, hence, the root source of hip-hop and rap culture is, by extension, African. I, therefore, argue that rather than viewing the West as the cradle of modernity, Kenyan urban youth are reclaiming a culture whose origin is really African; they are engaging in a reversed migration of an African 
culture, which was "exported" to the West. In addition, hip-hop and rap music and culture enable Kenyan urban youth to express the contradiction of living within the limits of their locality and to transcend them at the same time through engagement in the popular culture of the world. Although they engage in hiphop and rap music, they have adopted and altered it by using Sheng, rather than English, as the vehicle of the messages embedded in the music. A music genre that utilizes Sheng to convey messages represents for these youth a specifically Kenyan urban youth identity within the larger outside community. My observation here echoes that of Samper (2002), that globalization does not necessarily involve the adaptation of English and the western culture that it expresses.

When globalization is defined in economic terms, it can be conceptualized as a tool for oppressing a developing country such as Kenya. Although engaging in the global culture by Kenyan urban youth can be described as engaging in the natural act of sharing in the hybridized culture of the world, it can also be interpreted as collusion with globalization from an economic perspective. The consumption of popular culture of the world by these youth may be viewed as a complicit act that encourages economic exploitation by the West. This interpretation does not, however, apply to Kenyan urban youth's engagement in popular culture. These youth have engaged in globalization by subverting it and using it as an opportunity to place themselves in the world not only as consumers of the world capital but also as producers. Hip-hop and rap music and culture have provided them with an opportunity to create an informal cultural "industry" that produces and sells Kenyan hip-hop and rap music, lines of clothing, shoes, and deodorant, among other merchandise. Instead of resisting globalization as an oppressive tool, Kenyan urban youth have engaged it in a different way - challenging it in an economic "battle".

In consideration of Pieterse's (1994) proposal that globalization be conceived as hybridization, I examine ways in which the global elements that Kenyan urban youth have internalized can be considered to be hybridized as opposed to pure forms of global culture. The cultures that are represented by technology such as the Internet and devices such as cellular phones, and even hip-hop and rap music cannot quite be attributed to any particular group of people in any part of the world but are, in my view, representative of the culture of the world. They are hybridized cultures in that people in different localities draw from them and adopt them to reflect their local identities, like the Kenyan urban youth have done with hip hop and rap music. In addition, the influence of hip-hop music and culture has been found to transcend race. In 1998, for example, 81 million rap music CDs, tapes, and albums were sold, 70\% of which were purchased by Whites (Morrell \& Duncan-Andrade, 2002). This is indicative of the fact that this kind of music and culture is no longer associated with urban youth of color. In effect, this underscores the view that the borders 
between the local and the global are imaginary and fluid, rather than distinct and fixed. It also suggests that many people in the world may be living in the third space, which, although fraught with ambiguities and ambivalence, enables them to be innovative and collaborative in finding meaning of their existence (Bhabha, 1994) as prescribed by their different locations in the world.

\section{A PEDAGOGY OF POSSIBILITIES}

At a time when diversity (racial, ethnic, and class, among others) has proliferated and permeated into classrooms, teachers have been faced with the challenge of finding curricula and pedagogical strategies that are inclusive and affirmative, yet promote the development of academic and critical skills necessary for participation in a multicultural democracy (Morrell, 2002; Morrell \& Duncan-Andrade, 2002). According to McCarthy, Giardina, Harewood, and Park (2003), the process of globalization - the accelerated movement of people, economic and cultural capital images, ideas, as well as technologies across national boundaries, has intensely shaped all school knowledge. Particularly, the technological "revolution" (cable TV channels, home video technology, "explosion" of personal computers, and the internet) has increasingly affected the nature, production, dissemination, and exchange of information within a particular culture. This has had immense implications for institutions such as schools, which are involved in the cultural production and exchange of information and knowledge (Collins, 1994). Consequently, the increasing interdependence of the world requires that contemporary students be prepared for the changing reality brought about by globalization (McCarthy, et al, 2003).

A case for the relationship between popular forms of culture and education has been made by various scholars. McCarthy, et al (2003) argue that cultural globalization, rapid migration of cultural and economic capital, as well as electronically mediated images have immersed today's youth in popular culture both in their formal educational experiences and in the informal organization of their school learning. As a result, popular culture is at the centre of youth identity formation. According to them, popular culture locations are necessarily pedagogical sites in that it is through sites of cultural production (e.g., music and television) that youths from all races, gender, and classes learn about the rest of the world. These authors caution against taking popular culture as a mere expression of culture but instead, it should be seen as an important ground for political and social struggle, and that which offers opportunities for negotiation of the ever-shifting youth identities. Indeed, popular culture has the potential to support the process of democratic practice in education.

Popular culture has emerged as an important pedagogical intervention that opens up avenues for the youth to critically examine their educational experiences, question their taken-for-granted understandings of life, and explore the limits and possibilities of their assumptions on life (Dolby, 2003). According 
to Dolby, popular culture is intertwined with our lives, making it impossible to avoid, and, in many instances making it "tricky to draw a line between popular culture and the rest of our lives" (p. 258). Dolby argues that popular culture should be conceived as a cultural practice with its own power to transform people's lives through altering their social conditions.

Giroux and Simon (1989) underscore the importance of theorizing the significance of popular culture in the development of a theory and practice of critical pedagogy. They emphasize the important role of popular culture in education:

Educators who refuse to acknowledge popular culture as a significant basis of knowledge often devalue students by refusing to work with knowledge that students actually have and so eliminate the possibility of developing a pedagogy that links school knowledge to differing subject relations that help to constitute their everyday lives. (p. 3)

Giroux and Simon point out that the recognition of popular culture as necessarily pedagogical sites results in a kind of pedagogy that will be receptive to ways in which students actively construct meaning, that consequently determine their production of and response to classroom knowledge. Ignoring the cultural and social forms that are central to youth's experiences, on the other hand, results in educators risking silencing their students.

The utility of popular culture in education centers on its potential to enhance academic literacy as well as critical literacy, the kind of literacy that enables a critical examination, questioning, and challenging of the status quo, with the aim of emancipation from oppressive powers ( Morrell, 2002). Utilizing forms of popular culture (hip-hop music, film, TV shows, and media) in literacy development requires viewing them as texts (Morrell \& Duncan-Andrade, 2002). These texts can be useful in the development of language and literary skills that are needed for academic learning. Hip-hop music as text (print or audio) can, for example, be useful in teaching and learning literature, especially poetry and literary texts. Hip-hop music/texts, which are rich in imagery and metaphor, can be used to scaffold literary terms that are part of poetry terminology. They can also be used to teach other vocabulary pertinent to poetry such as tone, irony, and mood. In addition, hip-hop texts, which always have strong messages embedded in them, can be analyzed for themes, plot, and character development, which can be used as scaffolds for understanding these elements in an academic literary text (Morrell, 2002). Popular visual texts such as films and television shows can also be useful in advancing academic literacy skills (Morrell \& Duncan-Andrade, 2002). When used together with academic literary texts, these visual texts can form an important base for comparing and critiquing messages carried between them, resulting in the enhancement of the understanding of academic texts. In addition, they can provide students with 
opportunities for relating the two texts to their own experiences, thereby connecting literature, popular culture, and the students' everyday lives.

Popular culture texts used in teaching literary texts can be useful in enhancing literacy skills such as speaking, reading, and writing, such as when students are asked to read the texts aloud, to present to the class a critical analysis of a particular text, or even to write expository or critical essays on the information presented in the texts. An equally important benefit that students can gain from using texts from popular culture forms includes the development of critical awareness of not only a traditional educational system that produces and sustains oppressive forms of knowledge but also of the contemporary issues facing urban youth (Morrell, 2002; Morrell \& Duncan-Andrade, 2002). Knowledge reflected in popular culture texts can lead to discussions of social class issues, poverty, drug abuse, and injustices, all which relate to larger social, political, and power issues. Kenyan urban youth would, for example, become critical of the kind of education and knowledge that is available to them, in order to examine and criticize ways in which the (neo)-colonial legacy is still experienced in the curricula, preventing education from being responsive to their needs. Applied this way, forms of popular culture fulfill the demands of critical pedagogy through situating learning within the experiences of the learners, enabling students to engage in critical analysis of texts, and opening them up to larger social and political issues (Morrell, 2002).

While the above educational possibilities are attractive for Kenyan urban youth, the question of the power and politics behind the demand that English be used in schools as the only language remains a possible roadblock to the use of popular culture texts. Will the welcoming of texts that are not written in English or are in non-standard English be viewed as degrading efforts towards the mastery of English, or will they be viewed, as discussed above, as a means of enhancing competence in English language skills, and promoting the youth's academic success? Urban youth educators need to explore the possibilities promised by pedagogies that make connections between the academic world and the everyday experiences of their students. By making these connections, they will produce students who are critical members of their localities and beyond.

\section{CONCLUSION}

In this paper, I used the post-colonial notions of hybridity and the third space to examine ways in which Kenyan urban youth have challenged established codes of their identities. I argued that by living in a multilingual setting, these youth have embraced hybridity in terms of language, culture and identity. The ambivalence, ambiguity, and contradiction that they have experienced in the hybrid positions have opened up a third space in which they have re-considered, negotiated, and extended their positions. The negotiation of their identities in the third space has resulted in new ways of defining themselves, which have enabled them to embrace and express their ways of being in the various 
"worlds" to which they belong. Sheng, a "hybrid" language and a new way of positioning themselves between the hybrid languages and cultures of their parents and the larger youth and urban cultures has also served as a means for transversing the local and global worlds that are part of their lives. I finally engaged in a theoretical search for a pedagogy that would be useful to these youth in their third space positions. I discussed the utility of different forms of popular culture in their education as a basis for academic development as well as for raising critical consciousness in their lives. I, however, acknowledged the possible hindrances that such an endeavor may face due to the requirement of using English only as the medium of instruction, especially in schools in urban contexts in Kenya. However, a realization that popular culture would enhance mastery of English language and, consequently, students' academic success, may provide hope for a new pedagogy of possibilities.

\section{References}

Abdulaziz, M. \& Osinde, K. (1997). Sheng and Engsh: Development of mixed codes among the urban youth in Kenya. International Journal of the Sociology of Language, 125, 43-63.

Anzaldúa, G. (1987). Borderlands/La frontera: The new mestiza. San Francisco: Spinsters/Aunt Lute.

Ashcroft, B. (2001). Post-colonial transformation. London: Routledge

Ashcroft, B., Griffiths, G. \& Tiffin, H. (1989). The empire writes back: Theory and practice in postcolonial literatures. London: Routledge.

Ashcroft, B., Griffiths, G. \& Tiffin, H. (1995). General introduction. In B. Ashcroft, G. Griffiths \& H. Tiffins (Eds.), The postcolonial studies reader (pp. 1-4). New York: Routledge.

Asher, N. (2005). At the interstices: Engaging postcolonial and feminist perspectives for a multicultural education pedagogy in the South. Teachers College Record, 107, 10791106.

Bhabha, H. (1990). The third space: Interview with Homi Bhabha. In J. Rutherford (Ed.), Identity, community, and difference (pp. 207-221). London: Lawrence and Wishart.

Bhabha, H. (1994). The location of culture. London: Routledge.

Bosire, M. (2008). Sheng: The phonological, morphological and social profile of an urban vernacular. Unpublished doctoral dissertation, University of Albany, State University of New York.

Bosire, M. (2009). What makes a Sheng word unique? Lexical manipulations in mixed languages. Selected Proceedings of the $39^{\text {th }}$ Annual Conference on African Linguistics, Somerville, MA.

Collins, A. (1994). Intellectuals, power and quality television. In H. Giroux \& P. McLaren, Between borders: Pedagogy and the politics of cultural studies (pp. 56-73). New York: Routledge.

Dolby, N. (2003). Popular culture and democratic practice. Harvard Educational Review, 73, 258284.

Egejuru, P. (1980). Towards African literary independence. Westport: Greenwood press. 
English, L. (2005). Their-space practitioners: Women Educating for justice in the global south. Adult Education Quarterly, 55, 85-100.

Giddens, A. (1990). The consequences of modernity. Stanford, CA: Stanford University Press.

Giroux, H., \& Simon, R. (1989). Popular culture as a pedagogy of pleasure and meaning. In H. Giroux \& R. Simon, Popular culture, schooling and everyday life (pp. 1-29). Granby, MA: Bergin and Garvey.

Githiora, C. (2002). Sheng: Peer language, Swahili dialect or emerging Creole? Journal of African Cultural Studies, 15, 159-181.

Gutiérrez, K., Baquedano-López, P., \& Tejeda, C. (1999). Rethinking diversity: Hybridity and hybrid language practices in the third space. Mind, Culture, and Activity, 6, 286-303.

Hickling-Hudson, A. (2006). Cultural complexity, post-colonialism, and educational change: Challenges for comparative educators. Review of Education, 52, 201-218.

Hoogvelt, A. (1997). Globalisation and the postcolonial world: The new political economy of development. London: Macmillan.

Kiessling, R. \& Mous, M. (2004). Urban languages in Africa. Anthropological Linguistics, 46, $303-$ 341.

Kioko, A., \& Muthwii, M. (2003). English variety for the public domain in Kenya: Speakers' attitudes and views. Language, Culture, and Curriculum, 16, 130-145.

Kraidy, M. (1999). The global, the local, and the hybrid: A native ethnography of glocalization. Critical Studies in Mass Communication, 16, 456-476.

Mazrui, A. (1995). Slang and code-switching: The case of Sheng in Kenya. AAP, 42, 168-179

McCarthy, C., Giardina, M., Harewood, S., \& Park, J. (2003). Contesting culture: identity and curriculum dilemmas in the age of globalization, postcolonialism and multiplicity. Harvard Educational Review, 73, 449-465.

Momanyi, C. (2009). The effects of 'Sheng' in the teaching of Kiswahili in Kenyan Schools, The Journal of Pan African Studies, 12, 127-138

Morrell, E. (2002). Toward a critical pedagogy of popular culture: Literacy development among urban youth. Journal of Adolescent and Adult Literacy, 46, 72-77.

Morrell, E., \& Duncan-Andrade, J. (2002). Promoting academic literacy with urban youth through engaging hip-hop culture. English Journal, 9, 88-92.

Mule, L. (1999). Indigenous languages in the school curriculum: What happened to Kiswahili in Kenya? In S. Ladislaus \& J. Kincheloe (Eds), What is indigenous knowledge? Voices from the academy (pp. 227-242). New York, NY: Falmer Press

Ngugi wa Thiongo (1986). Decolonizing the mind: The politics of language in African literature. London: James Currey/Heinemann.

Ogechi, N. (2005). On lexicalization in Sheng. Nordic Journal of African Studies, 14, 334-355

Pieterse, J. (1994). Globalisation as hybridization. International Sociology, 9. 161- 184.

Prah, K. (1998). Between distinction and extinction: The harmonization and standardization of African languages. Witwatersrand: Witwatersrand University press.

Prazak, M. (1999). "We are on the run": Ideas of progress among adolescents in rural Kenya. Journal of African Cultural Studies, 12, 93-110.

Rosaldo, R. (1995). Forward. In C. Garcia, Hybrid cultures: Strategies for entering and leaving modernity (pp. xi-xvii). Minneapolis, MN: University of Minnesota press.

Samper, H. (2002). Talking Sheng: The role of a hybrid language in the construction of identity and youth culture in Nairobi, Kenya. Unpublished doctoral dissertation, University of Pennsylvania.

Sonaiya, R. (2003). The globalization of communication and the African foreign language user. Language, culture, and curriculum, 16, 146-154.

Spivak, G. (1999). A critique of postcolonial reason: Toward the history of the vanishing present. Cambridge, MA: Harvard University Press.

Spyropoulos, M. (1987). Sheng: Some preliminary investigations into a recently emerged Nairobi street language. Journal of the Anthropological society of Oxford, 18, 125-136

Trinh, T. (1989). Women, native, other: Writing postcoloniality and feminism. Bloomington: Indiana University press. 
Young, R. (1995). Colonial desire: Hybridity in theory, culture and race. London: Routledge.

Lucy Karanja has recently completed her $\mathrm{PhD}$ in the Faculty of Education at the University of Western Ontario. Her research interests include language use in classrooms, English as a Second Language (ESL) Education, refugee studies, qualitative methodologies, and postcolonial theory. She can be reached at lkaranja@uwo.ca or at luckaranja@gmail.com. . 